Genevieve Hudson - Marina Veverec i Blaž Martić

\title{
Posti, posti, posti
}

Ne javljam se na Ženine pozive. Sori, draga. Četkam jezik, gledam snimku pilatesa na internetu, evo me na masaži vrućim kamenjem. U stvari, i ne baš. U stvari, listam Tedin profil na Instagramu. Evo portreta Ted dok još nije imala djecu. Evo, portret Ted i njezina muža Nijemca u Barceloni. Evo, portret Ted u poluprozirnoj košulji od materijala kojem bi ona vjerojatno znala naziv - til? Šifon? Krep? Batist? Ted je tip žene koja zna takve nazive. Ted je tip cure koja piše blog o svom modnom izričaju. Zaustavim se na slici, zumiram. Opazim joj bradavice, nježna nijansa kestena ispod tanke tkanine. Lažem samu sebe i pretvaram se da je subverzivno kada jedna žena svodi drugu na objekt. Ipak, objekt je objekt je objekt. Ne mogu prestati gledati.

Evo brojnih verzija Ted tijekom proteklih godina.

Evo, portret Ted na kojem liže lizalicu. Jezik od tvrdog slatkiša. Šećer među zubima.

Trebala bih se javiti na Ženin poziv. Njezino ime u sans serifu ponovno mi prekrije zaslon, nada se da ćemo se vidjeti preko FaceTimea. Zamrači moj Instagram muzej. Dvorane sa slikama Tedina Života pretvore se u riječ, u ime osobe koju volim. Piše ŽENA. Ona je tip žene koja je verzirana u svim područjima osim u jednom: emocionalnom životu drugih. To je uopće ne zanima. Srce joj je hladna peć koju samo ja mogu ugrijati. Želi mi javiti da je upravo sletjela u Boston kamo je otišla povodom međunarodne pravne konferencije.

Šaljem joj poruku: Stigla si? Živa i zdrava? Oprosti kustos mi je na liniji dogovaramo se gdje postaviti kavez od mesa.

Žena i ja u otvorenom smo braku jer je to bolja opcija nego da je varam.

Portret Ted na kojem se prvi put tetovira. Opis: Imam tetovaže posvuda.

Točno tako. Tetovaže. Posvuda. Zašto to zvuči tako seksualno? Zato što je to i htjela. Znaš to. Tedine ruke prekrivene su tetovažama. Pregib njezina lakta ispunjavaju bojom. Labud širi krila preko njezinih prsa kao da će poletjeti. Komad sira leži joj na bicepsu. Kokoš joj spava na bedru. 
Sokol na srednjaku. Ukrštene kosti na palcu. Riječ TATICA na vratu. Patina svake od njih čini se presvježom, kao da se i sad mogu razmazati. Na fotografijama otprije par godina, sudeći po Instagramu, Tedino tijelo bilo je prazno platno, a plava kosa do ramena sasvim obična. Sada joj se crveni štakorski repić klati niz vrat. Meso iznad sjekutića probušeno je rinčicom. Oči govore: samo probaj, dušo.

Ted pokuca, otvorim joj vrata. Nalet hladnoće unese je unutra. Zagrlimo se u predsoblju ispod fotografije na kojoj guja guta miša. Zadnji smo se put vidjele prije mjesec dana kada mi je u studiju pomagala oko nove instalacije pod nazivom „Posti, posti, posti”, kojom ću uprizoriti osuvremenjenu verziju Kafkine priče „Umjetnik u gladovanju” tako što četrnaest dana, zatočena u kavezu od sirove govedine, neću ništa jesti. Moj će jedini zadatak biti ispunjavanje bojanki pastelama. Nakon stosatne probe koju sam prekinula votkom i Red Bullom i hotdogovima od pšeničnog glutena bila sam smušena. Ted mi je donijela gumene medvjediće u obliku Harryja Pottera da proslavimo kraj posta. Na hladnim smo pločicama isprobavale najnovije okuse: rigotina, šmrklji, blato, trula jaja, smrdljive čarape. Kada je zagrizla u medvjedića od ušnog voska, gurnula sam joj jezik u uho. U prvi mah učinila se preneraženom, a zatim kao da joj godi. Zadržala sam joj jezik u uhu i kružila, kružila, kružila, dok je ona jela gumene medvjediće jednog za drugim i hihotala.

„U redu je”, rekla sam joj. „Ionako sam u otvorenom braku.”

„Ja nisam”, rekla je, što je značilo da joj više ne smijem gurati jezik u uho.

Kaput joj je pun snijega. Ugledam je i dlanovi mi postanu skliski. U našem se zagrljaju osjeti ukočenost. Kralježnica joj se izravna pod mojim dlanom. Čemu nervoza? - pomislim, sumnjičava prema sebi. Samo ležerno. Njezin miris mi je poznat - eterično ulje ili nešto što se utrlja u zapešća i sljepoočnice da zaustavi glavobolju koja grebe do mozga. Miris sobe za meditaciju. Ordinacije za akupunkturu. Miris želje za oporavkom. Želim joj prisloniti nos na oko i udahnuti. Želim ponovo voditi ljubav s njezinim uhom, tamo gdje joj novi konus širi resicu u savršeno probušeno O. Odmakne se. Otrese sa sebe snijeg koji se rastopi u lokvice na podu, poslije ću se na njih poskliznuti.

Što Ted želi? 
Kaže mi da grad zbog zaleđenih kanala izgleda poput Avercampove slike. Zakolutam očima na spomen Avercampa, kako može reći nešto tako otrcano.

„Mrzim Avercampa”, kažem, a ona slegne ramenima.

Gradski kanali ljeti zaudaraju po nečemu trulom i tim prastarim plovnim putovima češljaju brodovi, uranjaju svoje magnetske krakove u tminu u potrazi za potonulim biciklima i smećem, čisteći prljavštinu. Jednom sam sjedila na klupici, pušila električnu cigaretu i gledala brod kako izvlači otpad. Njegov je krak izronio iz crne vode, omotan oko mrtvog tijela. Plijesan i ribe izjeli su lice, ali kao da je buljilo ravno u mene. Tako sam dobila ideju za Mrtvački kanal, novi performans u kojem sam rekonstruirala kartu Amsterdama i zamijenila kanale lešinama štakora odjevenim u frakove.

No danas su kanali hladne, čvrste, gotovo antiseptičke tvorevine. Ljudi preko njih prelaze kao da je stigla apokalipsa, poput Isusa, hodaju po vodi. Sve to djeluje kao predznak. Zamrznuti kanali u svibnju. Neće na dobro.

Ted prijeđe prstom duž keramičke posude sa sukulentom. To je jedina biljka koju ne mogu ubiti. „Mislim da si ga previše zalijevala”, kaže. „Izgleda napuhano i guli se.”

Misli na sukulent, koji možda ipak mogu ubiti. Hvala bogu pa je nervozna, čujem joj po glasu. Kao što uvijek kažem, razgovor trpi samo jednu nervoznu osobu.

Govori mi kako da se brinem o sukulentu, pa o problemima s novom dadiljom (stalno kasni i vrisku nagrađuje crtićima na Netflixu) i pritom dodiruje sve površine u stanu. Miluje lampu u obliku Zekoslava Mrkve, zalihe kontaktnih listova srednjeg formata, donji rub originala Davida Hockneya, šalicu u obliku T-Rexa koju sam izradila od gline. Pipka, pipka, pipka. Ruke su joj glomazne i nezgrapne. To su ruke koje grade. To su majčinske ruke.

Ne znam ništa o bebama, pelene nisam u životu promijenila, ne mogu zamisliti da mi spavaju u kući. Ted ima dvije bebe, blizance koji se zovu Pin i Fin, male vragolane koji ne žele spavati. Zamišljam Tedinu dnevnu sobu, naseljenu malim četama dinosaurusa, mrvicama integralnih keksa, tepihom koji otpušta blagi vonj ukiseljenog mlijeka. Uglavnom skriva majčinsku stranu, ali zapazim je tu i tamo (evo maramica za slinavi nosić, zaveži vezice, past ćeš) i onda me strujni udar znatiželje strese do nožnog palca. 
„Idemo odavde”, kaže Ted dok kopam po ormariću tražeći dvije šalice, a u kuhalu ključa voda za čaj.

Htjela sam da se izvalimo na kauč uz wimmins-only oolong, da sjedimo s vrelim šalicama u krilu i prinosimo ih ključnim kostima. Kada bismo dovoljno duboko utonule u jastuke, kada bi nam sjene navukle plave haljine na obrise, tko zna što bi se dogodilo?

„Aha”, kažem. „Želiš ići van?”

Ne želi da ovdje budemo same.

U sebi počnem nabrajati sve što sam danas pojela. Znak da gubim kontrolu.

BananaJogurtKomadićTamneČokoladeŠakaČipsa.

BananaJogurtKomadićTamneČokoladeŠakaČipsa.

BananaJogurtKomadićTamneČokoladeŠakaČipsa.

Trebala bih manje jesti, pripremiti tijelo za „Posti, posti, posti”. Izdržat ću svih četrnaest dana samo ako se počnem odvikavati od hrane, ako naučim želudac da traži malo, a onda ništa. Ali samokontrole gotovo i nemam.

„Keks?” kažem, podižući plavu kutiju Delfta s maslacem, koju sam kupila u suvenirnici niz ulicu. „Nećeš prvo keks?”

„Ako želiš umjetničku fotku, bolje je da te slikam vani i to što prije. Svjetlo, svjetlo je...”

Digne ruku i prstima pokaže onaj znak za OK umjesto da to samo kaže. Zrake zime udaraju u prozor iza nje, tekstura je savršena, čista nijansa plave.

Jebene umjetničke fotografije.

Jesam li zaboravila da nam je to bio plan? Ili sam se nadala da je ona zaboravila? Uopće mi ne trebaju nove fotografije. Obožavam ovu koju trenutno imam jer na njoj izgledam kao da režim na fotoaparat, uvrnuta pogleda, gornje usnice izvijene kao da sam spremna ujesti. Pretpostavila sam da je Ted shvatila što želim, da je moj poziv bio izgovor za druženje, prilika da se intimno povežemo. Čak mi se i ne sviđaju njezine fotografije - a kome se sviđaju? Ljudi bi trebali bolje čitati misli. Ozbiljna sam. 
Otvorim joj ulazna vrata uz gestu poslije vas, mlada damo, ali sada znam da ne čita misli pa nemam pojma kako je to shvatila. Zima hrli prema nama. Na izlazu Ted me preko flanela dotakne po trbuhu, prolazeći pored mene istim hodnikom kojim je netom prije ušla. Uvijek je tako, čim smo na sigurnom, na ulici, strejt cure počnu flertati. Lagano gubim živce, ali onda se okrene prema meni i vidim da se našminkala prije nego je došla k meni. Sloj pudera na obrazima. Iznad očiju tračak zelene. Dno kapka zaoštreno crnim tušem. Dirnuta sam gestom, i premda sam sigurna da se svaki dan šminka za svakoga, ipak ima nešto ranjivo u tome kada se žena trudi izaći ljepša u svijet. Smekšam se.

„Podsjećaš me na najbolju prijateljicu iz srednje škole”, kaže mi dok hodamo.

Ključna riječ - prijateljicu. Baš suptilno, Ted. No to je jedna od tema kojima se želim baviti u sljedećem performansu: kako odnose iz prošlosti projiciramo na ljude koje poslije upoznajemo. Nižemo osjećaje od jedne do druge osobe dok se sve niti ne zapletu u zamršeno klupko onoga što oni zaista jesu i onoga što očekujemo da budu i više ih ne možemo raspetljati. Već sam smislila ime performansa: „Niti toliko puno niti toliko sigurno”.

„Pričaj mi o toj prijateljici”, kažem.

Ted se namršti, slegne ramenima. Ponekad imamo i previše toga da bi se ispričalo. Imala sam i ja svakakvih prijateljica. Jedna je od njih i prijateljica iz srednje u čijem smo se bračnom krevetu svake večeri trljale jedna od drugu, dok su nas sa stropa promatrale plastične zvijezde posložene u sazviježđe Velikog psa. Takva prijateljica, Ted?

Na ulici, uz rubove zamrznutih kanala šepaju labudovi, protjerani iz domova koji su prenamijenjeni u klizališta. Nadlijeću ih papige, egzotične zelene ptice koje podrhtavaju zrakom, seleći se od parka do parka. Muškarci zajapurenih lica s ožiljcima od vodenih kozica i pijanih, odsutnih očiju djeci prodaju vruću čokoladu. Požudno gledaju. Majke šeću sa svojim bjelokosim bebama sve do ruba leda, gdje prokližu i padnu, ali se ne utope. Žena s bradom podvučenom pod vrat nekome pokušava prodati stare klizaljke.

Kad sam se tek doselila u Amsterdam, nikako se nisam mogla priviknuti na svu tu vodu. Pored vode nema mirovanja. Samo pokret, struja, uvijek neko mreškanje, uvijek neke mijene. Kanali se protežu gradom poput arterija, pulsiraju i kucaju i preplavljuju ga pokretom. Svaki bih dan plivala 
unatraške slanim morskim mozgom grada. Zaronila bih u kadu dok mi se prsti ne bi smežurali. Zatvorila bih oči i zamislila, osjetila nadimanje crnog mora preko rubova brane, razbijanje bijesnih, vjetrom nošenih valova o zapadnu obalu, njihove izdisaje prema kopnu, sve dok jednoga dana ne preostane ništa što natopljeni morski dlan nije poklopio. Godinama sam se osjećala kao da mi se mozak utopio. Nisam mogla razmišljati. U sljepoočnom mi je režnju padala kiša, neprestano sumorno rominjanje. Oblaci su se kretali i lijevali mi maglu u hipokampus. Treptajima bih tjerala kondenzaciju koja je sve obavila vodenastom omaglicom.

Žudjela sam za surovom, suhom vrućinom. Željela sam sjesti na isušeni pijesak u pustinji kojoj je sunce rastvorilo tlo, izazivajući ga da diše. Htjela sam izgorjeti toliko da dobijem melanom. Htjela sam osjetiti kako mi sunce prži meso. Voda u gradu nastavila je rasti. Bujala je. Gutala. Curila mi je iz usta.

No sada kada je zima isisala kondenzaciju iz zraka i umrtvila kanale, pretvorivši ih u nešto tvrdo poput mramornog poda, sada kada sige vise kao zubi s rubova cerada i prijete da će se odlomiti i probosti te, sada kada je snijeg sve pretvorio u spokojnu sibirsku visoravan, sada mi fali voda. Prvi put nakon dugo vremena udahnem punim plućima i shvatim. To tipično ponašanje. Tu neutaživu želju za onime što ne mogu imati.

Moja Žena nema snažan seksualni poriv. Ali seks nije razlog za naš otvoreni brak. Radi se o drugačijoj požudi, o nečemu dubljem od seksa - o nečemu što graniči s opsesijom. Naime, ne znam se normalno ponašati kad sam kraj nekoga tko mi se sviđa, bez obzira na to je li mi prijatelj ili nešto više. Ne mogu upoznati nekog zanimljivog i biti opuštena. Kad mi se netko sviđa, pretvorim se u vlak koji punom parom juri nizbrdo, bez kočnica. Žena se naviknula na to. Kad je riječ o Ted, rekla bih da je sjeme znatiželje proklijalo one noći kad smo se upoznale, na vjenčanju zajedničkog prijatelja u Westerfabrieku. Njezin se muž gnijezdio u kutu, jeo kobasice i ćaskao s grafičkim dizajnerom koji je smatrao da su logotipi koje je napravio za neke internetske brendove „umjetnost”. Prišla mi je jer me prepoznala s moje prošlogodišnje izložbe „Nisam ja, ja sam”. Izložba je bila fijasko. Mediji su je popljuvali, a ja sam izgubila agenta. Čak sam i ja znala da je izložba promašaj i k tome loše izvedena, ali iz Tedine sam sramežljivosti zaključila da je njoj bila briljantna. Njoj koja je stajala ondje s plastičnim tanjurićem cruditésa u ruci, baš kao prava žena. Naravno da se njoj svidjela izložba. Nije znala što valja. Oblačila se kao i svi drugi, samo bolje. 
Kao da je iz prostorije usisala svu nadu i dobrotu. Ozbiljno. Sve je ostalo bilo blijedo naspram Ted. Kao da se u njoj vrpoljio život, tražeći izlaz. Ja? Jesam li ja bila izlaz? Jesam li ja bila život? Zatim se smijala, velikim dlanom pokrivala usta i vidjela sam da je progutala riječ umjesto da je izgovori, i pomislila sam: Koju riječ? Koju si riječ progutala, Ted?

Ted me namjesti uz ogradu od kovanog čelika na mostu, u pozadini su klizači. Idila. Najgora moguća pozadina za umjetničke slike. O, Kriste. Nikad in neću iskoristiti.

„Nasmij se”, kaže. „Hoću širok osmijeh.”

Očarana sam njezinim samopouzdanjem. Zapamti to, kažem si. Zapamti da će ljudi povjerovati u bilo što ako si dovoljno sigurna u sebe. Obožavat će tvoju umjetnost ako budeš malo samouvjerenija.

Ted me slika, na prvoj izgledam kao da me netko škaklja, na drugoj prislanjam bradu na šaku, na trećoj zabacujem ruke iznad glave kao da u svijetu nema patnje. Možda će ova biti dobra. Možda me Ted vidi jasnije nego bilo tko drugi.

Možda, možda, možda.

Mrzim tu riječ.

„Eto ga”, kaže.

Priđe mi toliko blizu da mogu osjetiti miris njezina eteričnog ulja. Zatakne mi pramen kose iza uha. Kad se nasmije, pozdravi me piercing u zubnom mesu.

„Ništa lakše”, kaže. „Ti, tako si lijepa.”

Komplimenti, obožavam ih. Želim joj se zavući u naručje. Dopustim joj da me pogleda ravno u oči. Oči su joj paragrafi ispisani na stranom jeziku. Kad bih mogla, unijela bih njezin izraz lica u Google prevoditelj. Što uopće može značiti?

„Ti”, kaže. „Ti, ti, ti.”

„Ti”, uzvratim. Glas mi je dubok i ne zvuči kao moj. „Ti.”

Nešto će se dogoditi. Snijeg oko nas pada kao da smo prizor prilijepljen na dno protresene kugle. „Ja”, kažem, a moj je glas opet moj. 
Tada se začuje. Tonac s kojim sam dijelila studio u Americi rekao mi je da pucanje leda zvuči kao da vanzemaljci pjevaju. iPhone mu je bio pun onih sablasnih zvukova jeke. Putovao je u Minnesotu, Vermont, Aljasku da snimi kako se led pomiče i topi i puca. Zvuči kao svjetlosni mač koji reže zrak, potpuno drugačije od onoga što sam zamišljala. Zbog toga znam što se događa i prije nego što pogledom uhvatim prizor. Čujem pjesmu vanzemaljaca. Čujem kako svjetlosni mač izlazi iz korica i para zrak. Ted vrisne. Okrenem se i pogledam prema kanalu, i ugledam, cijeli je kanal krcat ljudima - majke i djeca, debeli muškarci i pogrbljene bakice u šaci užasa - dok se led pod njima izmiče i puca i zjapi. Led je zub čeljusti koja in želi progutati. Eno odlaze, tijela, u živu i opaku crnu vodu koja čeka da ih pojede. Čeka da mu skliznu niz zaleđeno grlo od kojega zastaje srce. O bože, pomislim. Ted me uhvati za ruku i prisloni je na srce. Njezino mi srce glasno tuče o dlan. Njezino me srce udara. Pogledam je, ona me uslika. Ne smijem se, a tko i bi, kada se toliko ljudi utapa.

\section{(c) (i) $\odot$}

Creative Commons Attribution-NonCommercial-NoDerivatives 4.0 International License 